Volume 13(1), 2019

Page: $63-80$

\title{
Analysis of Nazhir Accountability Implementation in Empowerment of Productive Waqf in Indonesia
}

\author{
Henik Hari Astuti ${ }^{1}$, Yuswar Z. Basri, and Hendri Tanjung
}

\begin{abstract}
This study aims to find constraints or problems in applying accountability, find solutions and strategies that can be done by nazhir and related institutions, namely Ministry of Religion and BWI using the ANP (Analytical Network Process) method. This research was conducted in the period 2015 to 2018. The results of this study indicate that many problems in the implementation of accountability include people's understanding of waqf is still low, nazhir is not professional, the system is inadequate, nazhir is not transparent and BWI and Ministry of Religion are not optimal. The implications of this research are in the form of a theory of problem mapping formulation, accountability strategies and solutions that can be applied by nazhir, BWI and Ministry of Religion as productive waqf management organisations to increase their productivity to improve the welfare of the people.
\end{abstract}

Keywords: Productive Endowments, Nazhir, Accountability, and ANP (Analytic Network Process)

Abstrak. Penelitian ini bertujuan untuk mencari prioritas penerapan dimensi akuntabilitas, mencari solusi yang dapat dilakukan nazhir serta membuat strategi yang harus dilakukan oleh nazhir dan Lembaga-lembaga terkait yaitu Kemenag dan BWI yang dilakukan dengan menggunakan metode ANP (Analityc Network Process). Penelitian ini dilakukan dalam rentang waktu antara tahun 2015 sampai dengan tahun 2018. Hasil penelitian ini menunjukkan masih banyak masalah dalam penerapan akuntabilitas diantaranya adalah pemahaman masyarakat tentang hukum wakaf masih lemah, nazhir tidak professional, sistem yang tidak terintegrasi, nazhir tidak transparan serta peran BWI dan Kemenag belum maksimal. Implikasi dari penelitian ini adalah identifikasi permasalahan dan solusi yang bisa diterapkan oleh nazhir, BWI dan Kemenag untuk meningkatkan produktifitas mereka agar dapat membawa maslahah untuk umat.

Kata kunci: Wakaf Produktif, Nazhir, Akuntabilitas, dan ANP (Analytic Network Process)

${ }^{1}$ Islamic Economic \& Finance, University of Trisakti | henik.astuti@gmail.com 


\section{Introduction}

Indonesia as a country with the biggest Muslim population number in the world has the potency to be a country with big and powerful Islamic economy power (Djunaidi \& Asyhar, 2006). One of such Islamic economy potency shall be waqf (endowment). Waqf becomes one of special worship as the reward continuous even the endowing person has passed away (Mubarok, 2008). In Indonesia, waqf gets more serious attention. According to Helza (2015) many kind of steps has been made by Indonesian government in providing with broad support for waqf development. Waqf has big potency and be able to be alternative financing in nation development besides State Budget (APBN) if it be productively empowered. But in the fact productive waqf has not been maximally and effectively functioned (Darwanto, 2012). Cash waqf also intensively be improved since Majelis Ulama Indonesia (MUI) issued fatwa (advice) regarding on cash waqf on 2002. Cash waqf is considered as one of solution which able to make waqf be more productive, due to that cash not only used as exchange tool but also used to empower dormant national asset waqf (Rasyid,2016).

Based on result of National Work Force Survey of Statistic Center Data (Survey Angkatan Kerja Nasional Data Pusat Statistik), February 2018, potency of cash waqf shall be IDR 30.6 billion per year. Accountability is one important factor that nazhir shall put an attention in productive waqf management. Nazhir ability in understanding accountability system is much required so able to provide with right and accurate financial information. Accountancy information is not limited to financial statement, but more broaden shall be all information regarding on an business entity required to be used as decision making basis by the relevant parties (stakeholder).

Based on background as above described then this research problem formulation shall be as follows: (1) What kind of problems (constraints) faced by nazhir in implementation of productive waqf management accountability dimension? (2) What kind of solutions can be made by nazhir in implementation 
of productive waqf management accountability dimension according to the experts? (3) What kind of strategies which can be made in implementation of productive waqf management accountability dimension according to the experts?

\section{Literature Review}

Ihsan (2007) studied waqf accountability in Indonesia. He concluded that: (1) Waqf practice at this moment has not had management and accountancy standard in waqf management; (2) Indonesian Waqf Board as authorized institution shall improve Law of waqf management includes it accountancy aspecs; (3) Waqf management and accountancy standard is much substantial due to will affect to transparency and accountability to public.

Osman (2010) examined the accountability of waqf management. He stated that in order to increase waqf management, accountability should not only be considered in it technical side (e.g.: audit, accountability and reporting) more over accountability also should be considered from organization ability in it involving in managing, distributing, and reporting waqf asset management activities.

Budiman (2011) researched accountability of waqf management institution in Indonesia and concluded that accountability shall be a process where an institution considered itself be openly responsible regarding on any matters conducted and not conducted. Operationally accountability is realized in a form of reporting, involving, and responding. Accountability may rise public trust to the institution, therefore accountability becomes a substantial matter due to it will affect legitimation upon waqf management institution.

Ihsan (2011) researched two waqf manager institutions, one is a new institution which focuses on accountability and transparency in waqf management eventhough without having sophiscated information technology, the other one is waqf management institution which has managed waqf assets for many years, having professional staff and sophiscated technology. Research result was the new institution which focused on accountability and 
transparency showed impressing ability in managing waqf assets all the year, while the old institution tended stagnant in managing its waqf assets for the last decades. It showed that accountability and transparency much depends on how big it will to apply it.

Asytuti (2012), in her research stated that increasing of productive waqf fund may be made by socialization, education and information. Related to management mechanism and financial reporting on waqf institutions, in order to reach public trust, it required to apply transparency and accountability. Therefore in managing waqf fund, waqf nazhir of course shall make financial statements regularly which easily accessible by waqif, nazhir may productively manage waqf fund so it may empower poor peoples' economy.

Ridwan (2012) concluded that professional nazhir which has reliable human skill, human technicalandhuman relation shall be a figure of general leader of waqf institution which be able to reach waqf purposes, and system of Integrated Quality Management shall be a system which required to be comprehended by professional nazhir to run it duties and obligations includes: (1) Increasing feasibility of waqf asset production so it can reach ideal target to provide with the most advantages for waqf purposes; (2) Protecting waqf asset sources by conducting proper maintenance and protection in investing waqf asset and eliminating investment risks; (3) Firmly hold on waqif conditions, either related to type of investment or distribution of waqf asset products; (4) Providing with information to waqifs and supporting them to give new waqf, as well as providing with counseling or advice in order to be established professional waqf institution.

Masruki, et al. (2013) stated that accounting may improve practice of waqf goods management by waqf institution so it may account for mutawalli. The absence of accounting standard on waqf management becomes the main reason so there is lack of equal accounting application amongst waqf institutions. Accountability becomes the most appropriate element to be used by nazhir in their responsibility on the waqf goods which are under their control. 
Huda, et al. (2014), also has made research regarding accountability as a solution of waqf management especially in West Sumatra and Riau. In this research it was described that problems in waqf management in such both regions, firstly there was accountability problem on it waqf management institution (nazhir) shall be in waqf law socialization which shall be deemed much lack, while the second accountability problem there was lack information to get waqif, and the third accountability problem there was the same of priority products which may be caused by a similarity of model hierarchy.

Siraj (2015) studied Waqf Management in Malaysia. The result showed that only few waqf institutions in Malaysia which have applied strategic planning system, high turn-over level belongs to operational staffs and top management which suspected became the main factor of the slow of strategic planning execution, while the smaller organization which financed by itself paid more attention to strategic planning than bigger organization which is financed by the government.

Ihsan, et al. (2016) studied accountability mechanism for awqaf institutions. It is concluded that: (1) It is time that waqf regulation board (in this event shall be BWI) introduces and improves roles regarding on mutawali's responsibility due to so far there was no fixed guidelines regarding on how accountability should be applied; (2) the most urgent regulation at this moment shall be a standard of waqf accounting and indicator of mutawali's performance assessment; (3) Study regarding on accountability of waqf institution at this moment remains much limited, it is required more studies regarding on comparison between two countries in matter of implementation of waqf institution accountability.

Siswantoro, et al. (2017) researched Islamic Accountability Index of Cash Waqf institution in Indonesia. It is concluded that to establish accountability index for cash waqf institution in Indonesia is required to enable to be used to compare and increase an awareness upon accountability component within board institutions. Waqf management institution needs competent human resources to prepare good accountability index. The most substantial issue in 
cash waqf management shall be executing financial report audit and compliance with Islamic precepts. Waqf management institution not only performing waqf asset management activities but also required to made reporting to public to increase its accountability by disclosing financial information and it activities in several ways, one by using social media and internet.

This research is a qualitative descriptive research by using ANP (Analytic Network Process) approach which has non parametric and nonBayesian nature/ no needs normality assumption (Ascarya, 2005). On qualitative research hypothesis is not formulated, but it expected can be found a hypothesis while research process (Sugiyono,2009). According to Irawan (2006), qualitative research is not started by proposing hypothesis and testing such hypothesis truth, qualitative research is started from the bottom by collecting data as much as possible regarding on an issue, and from such collected data then finds out patterns, law, as well as principles, and concluded with making research conclusion. This research framework shall be as follows:

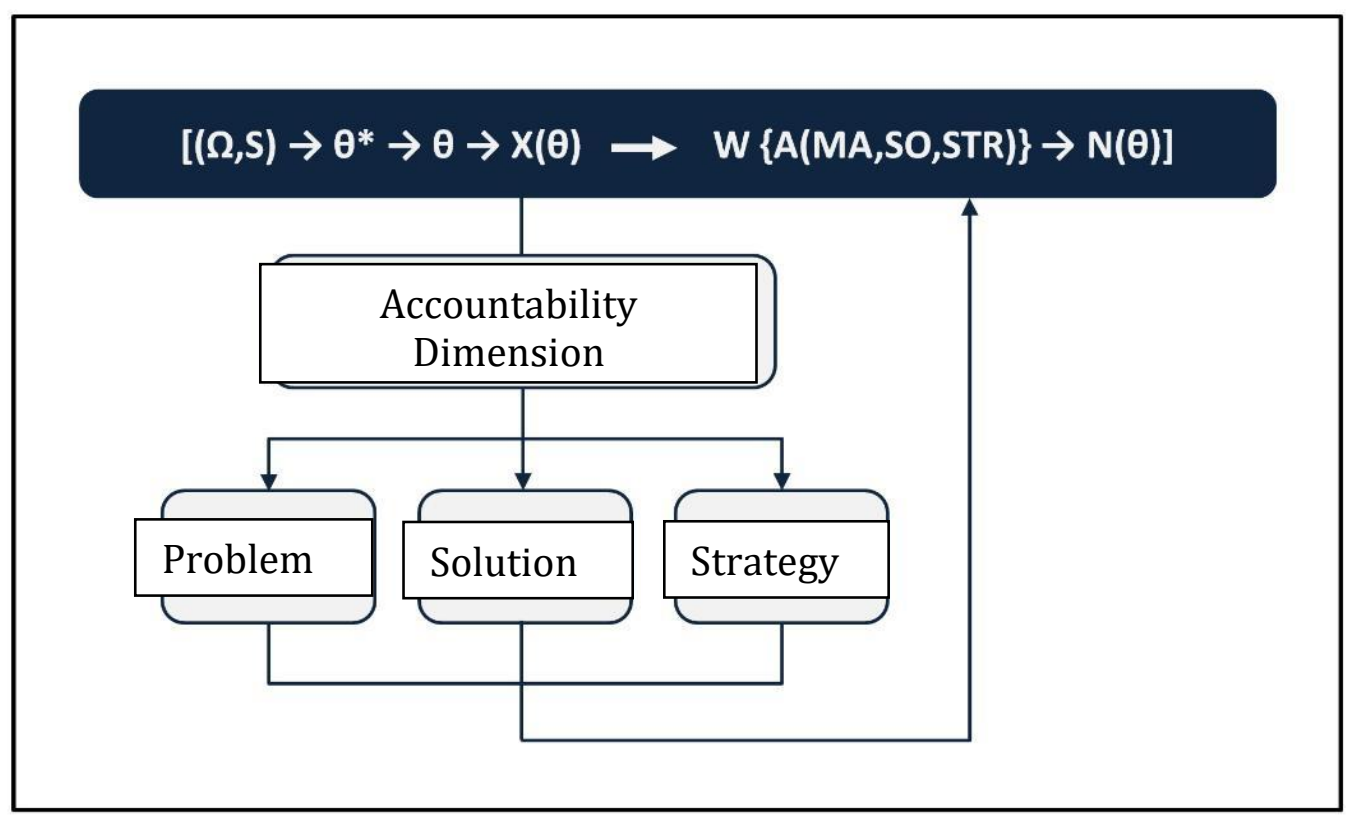

Figure 1. Research Framework

\section{Method}

Design of this research uses qualitative descriptive research method by triangulations, either triangulation of theory, method or data source. The choice 
of qualitative descriptive method research due to research problem as formulated needs qualitative answer, given answer needs in-depth description. In qualitative research no need to firstly propose hypothesis and testing such hypothesis truth, qualitative research is started from the bottom by collecting data as much as possible regarding on an issue, and from such collected data then finds out patters, law, as well as principles, and finished by making research conclusion (Irawan, 2006).

Some methods will be used in data collecting in this research, namely: Literature study, Interview, Observation and Questioner. Data analysis technique will be used in this research shall be: Pre - in field analysis and analysis while in the field, includes: data reduction, data display, dan conclusion drawing/verification.

ANP method was chosen by researcher due to constitute one of most visible method for respondent, as well as much compatible with tauhid principle as improved by Masudhul Alam Coudhury in Tauhidi String Relation (TSR) methodology. In ANP analysis number of sample/respondent was not used as validity standard (Ascarya, 2005).

ANP method is general theory used to decrease composite priority ratio from personal ratio scale which reflects relative assessment from mutual interacting elements impact regarding on control criteria (Saaty, 2003). ANP is a mathematic theory enable an individual as decision maker faces factors which have connection each other (dependence) and feedback systematically. ANP method considerably a new approach in qualitative research which constitutes improvement from previous method i.e. Analytic Hierarchy Process (AHP) (Tanjung \& Devi, 2013).

Model Construction Phase based on literature study and in-depth interview with the experts and questioner on the first phase, then established a research model. Model was established use software Super Decision. This Software is adequate popular used in ANP research.

Model Quantification Phase based on observation result in the field, questioner result from nazhirs, and indepth interview with experts, researcher 
prepared questioners and distribute ANP questioners of pairwise comparison inter elements within cluster. Questioners were distributed to nine waqf nazhir experts who are fully competent in waqf accountability sector, represents academist, practitioner, and regulator in waqf in Indonesia.

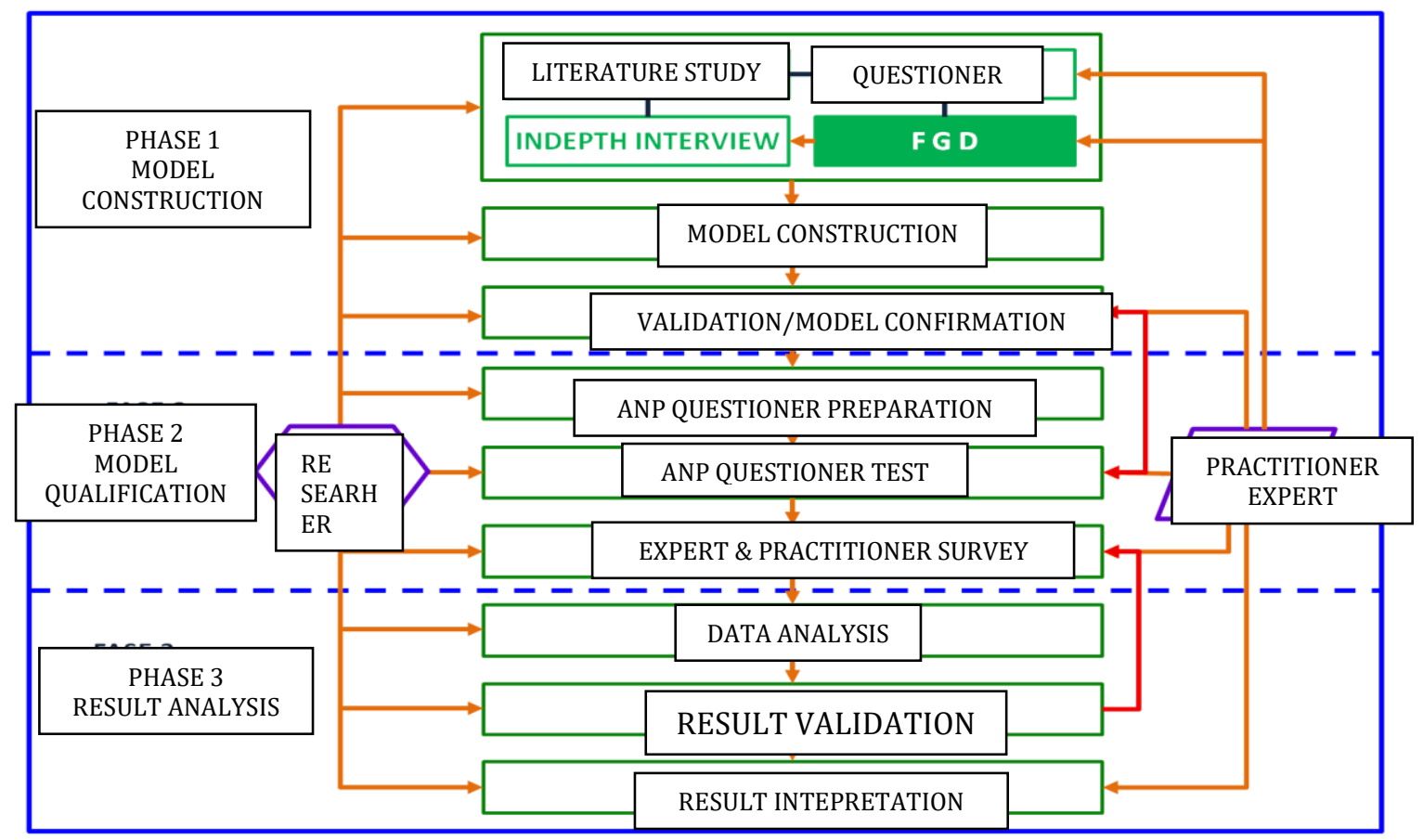

Figure 2. Research Steps (Ascarya, 2005)

\section{Results and Discussion}

Problems or constraints as faced in financial accountability are : accountability, transparency, budget, absence of periodic report, un-audited (Muhammad, 2002). Problems or constraints as faced inlegal and honesty accountability are: Nazhir has not registered in BWI, has not comprehended Waqf Law, has not had any commitment, has not firmly hold on Al Quran and hadist, non-compliance with sharia (Budiman, 2011). Problems or constraints as faced in program accountability are: made program has not in accordance with it function, program has not produce maximal results, nazhir has not made waqf improvement innovation program, program has not corresponded to public needs, program has not been effective and efficient (Kasdi, 2014).

Problems or constraints as faced in policy accountability are: nazhir has not applied transparency principle, policy has not been useful, taken policies 
have not been able to increase people's wealth, not transparent in choosing mutawali, nazhir's policies have not been professional (Ridwan, 2012). Problems or constraints as faced in process accountability are: low public awareness in waqf, lack of waqf socialization, absence of integrated system, has not reported its performance, not transparent (Damanhuri, 2012).

From Questioner result given to the experts, result of ANP process in super decision software presented conclusion result based on geometric mean to stipulate entirely priority sequence. Result of rater agreement (W) of all respondent is $82.71 \%$ means that level of inter-respondent deal upon priority level on criteria cluster is high. From ANP data process as above presented it shows that according to research respondents consist of experts in waqf sector it produced accountability priority sequence required to be applied by productive nazhirs as follows:

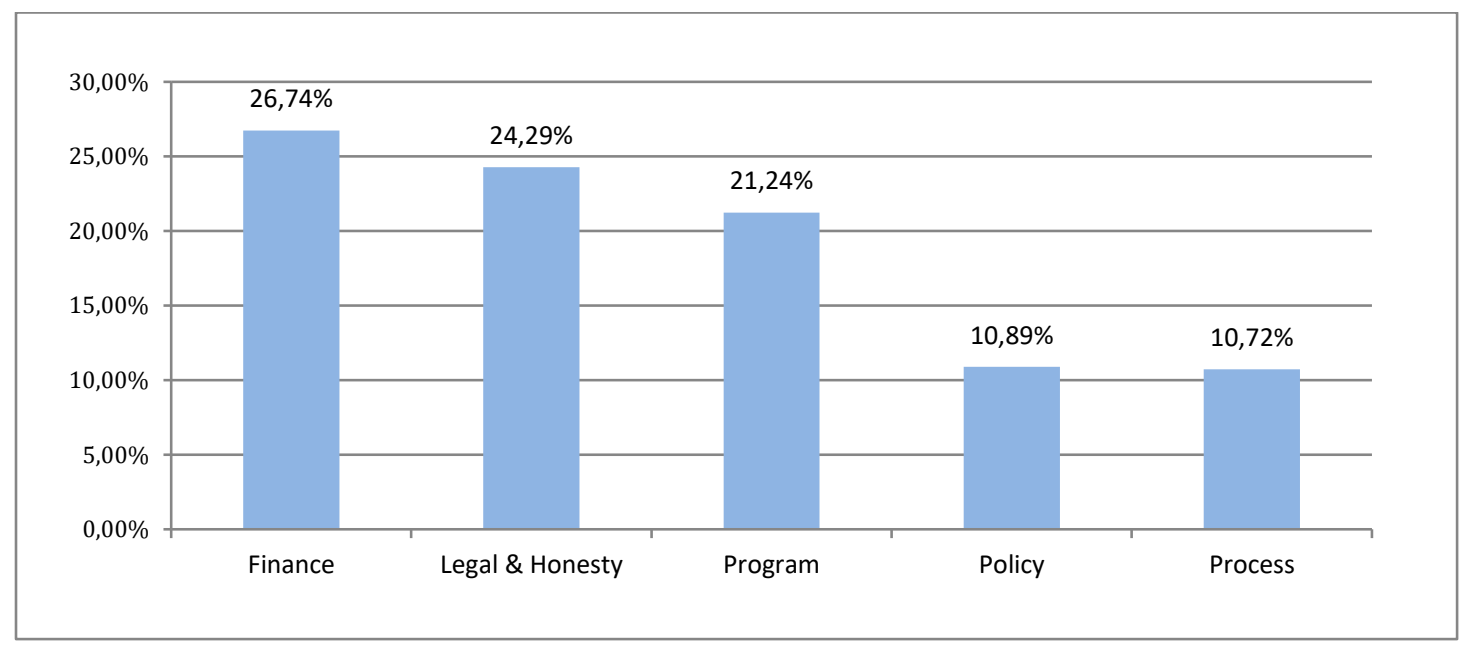

Figure 3. Accountability According to The Experts

In calculation of local grade, it has been confirmed that all pair-wise comparisons have reached inconsistency level $<10 \% / 0.01$. Result of agreement (W) of all respondents is $52.35 \%$ means that inter-respondent deal level upon priority level on criteria cluster of financial accountability is adequately high. Elements which become priority in this accountability cluster are: 


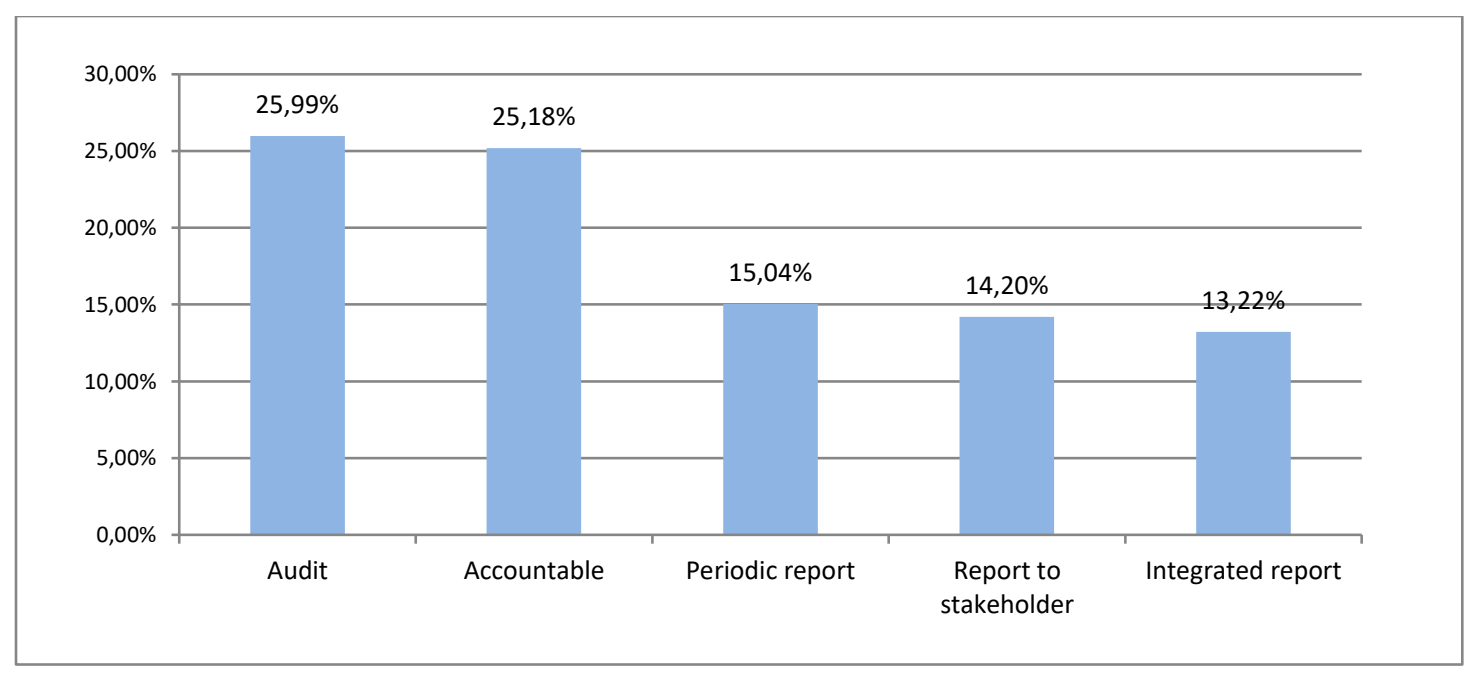

Figure 4. Financial Accountability Solution Criteria

Based on result of data process which has been confirmed that all pairwise comparisons have reached inconsistency level $<10 \% / 0.01$. Result of agreement $(\mathrm{W})$ of all respondents is $49.13 \%$ means that inter-respondent deal level upon priority level on criteria cluster of legal and honesty accountability is high. Elements need to be concerned and made in this legal and honesty accountability is sequenced based on priority and primacy scale as follows:

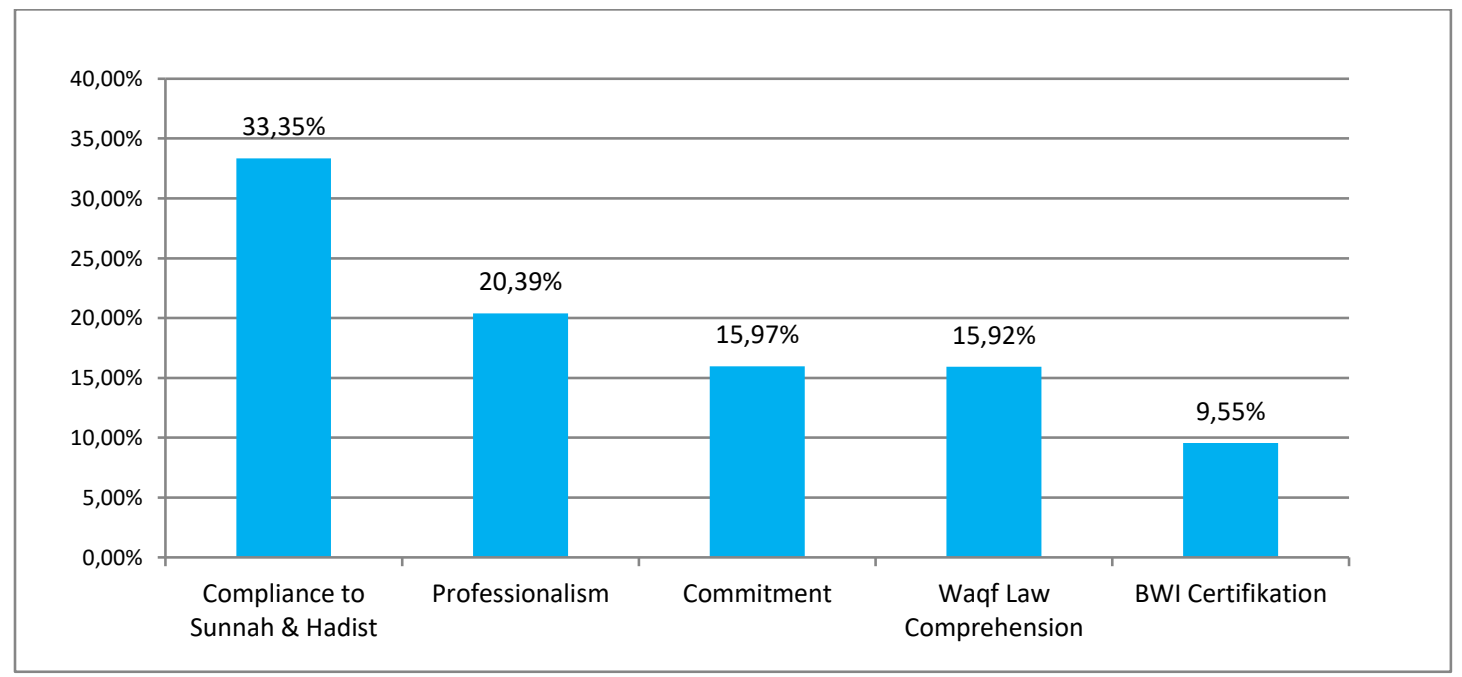

Figure 5. Legal and Honesty Accountability Solution Criteria

Priorty in stipulating nazhir accountability solution in productive waqf empowerment in Indonesia corresponds to sharia principles under grade of $33.16 \%$, then followed with public need of $15.91 \%$, applying transparency of $15.80 \%$, giving maximal result of $15.70 \%$ and at the last priority is accountability 
of $15.44 \%$. In calculation of local grade, it has confirmed that all pair-wise comparisons have reached inconsistency level $<10 \% / 0.01$. Result of agreement (W) of all respondents is $36.54 \%$ means that inter-respondent deal level upon priority level on criteria cluster of program accountability is adequately low. There are (4) elements become priority in this implementatioin of program accountability, as follows:

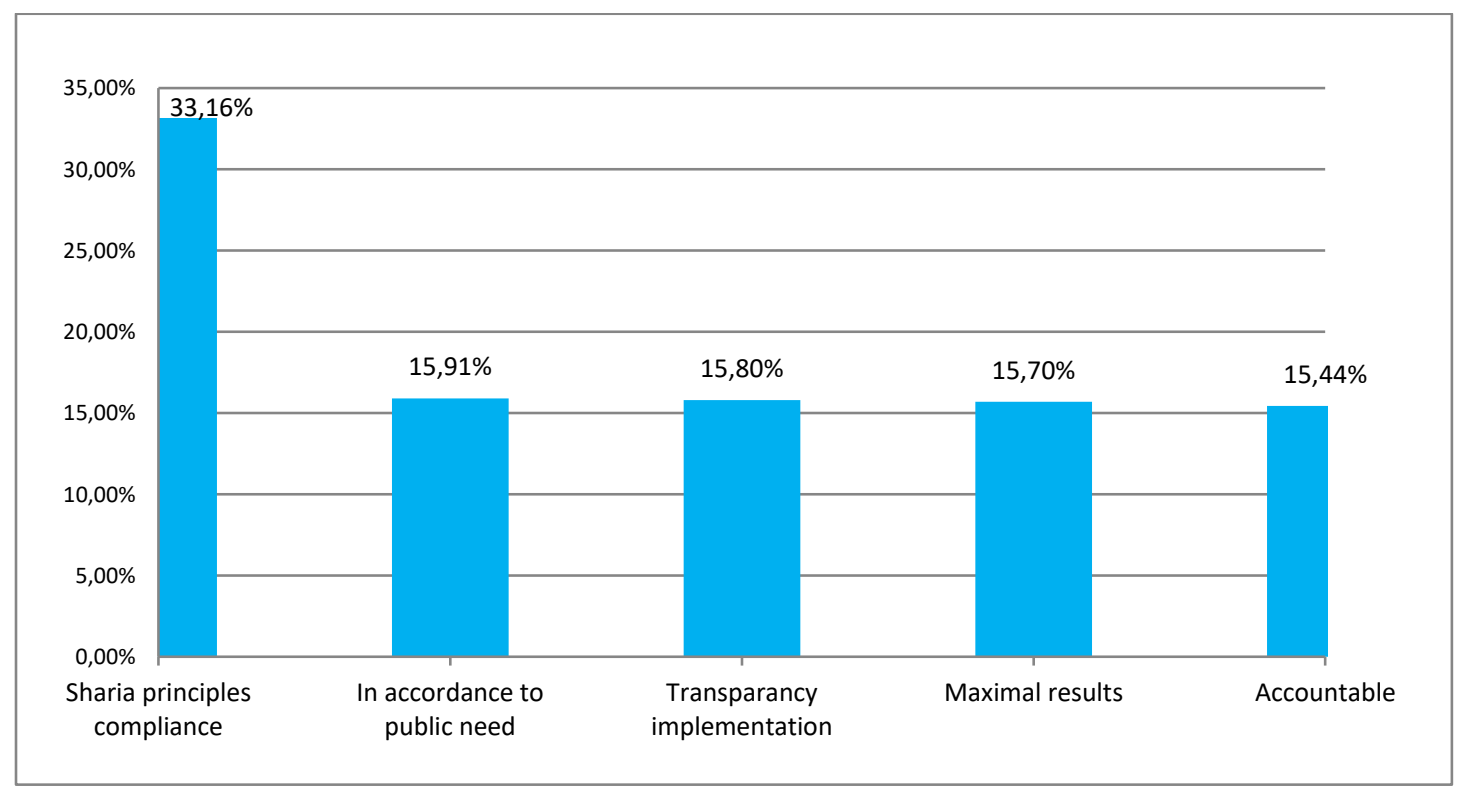

Figure 6. Program Accountability Solution Criteria

Priority of policy accountability cluster according to each and all respondents shows that the most priority policy accountability criteria in stipulating nazhir's accountability strategy in empowerment of productive waqf in Indonesia is in accordance with Al-Qur'an and sunnah under grade of $32.92 \%$, then followed by in accordance with it purposes of $22.90 \%$, accountability of $14.90 \%$, the transparent system of $12.91 \%$ and in the last priority is effective and efficient of $12.81 \%$. In calculation of local grade, it has confirmed that all pair-wise comparisons have reached inconsistency level $<10 \% / 0.01$. Result of agreement (W) of all respondents is $59.30 \%$ means that inter-respondent deal level upon priority level on criteria cluster of policy accountability is adequately high. There are (4) elements become priority in this implementatioin of policy accountability, as follows: 


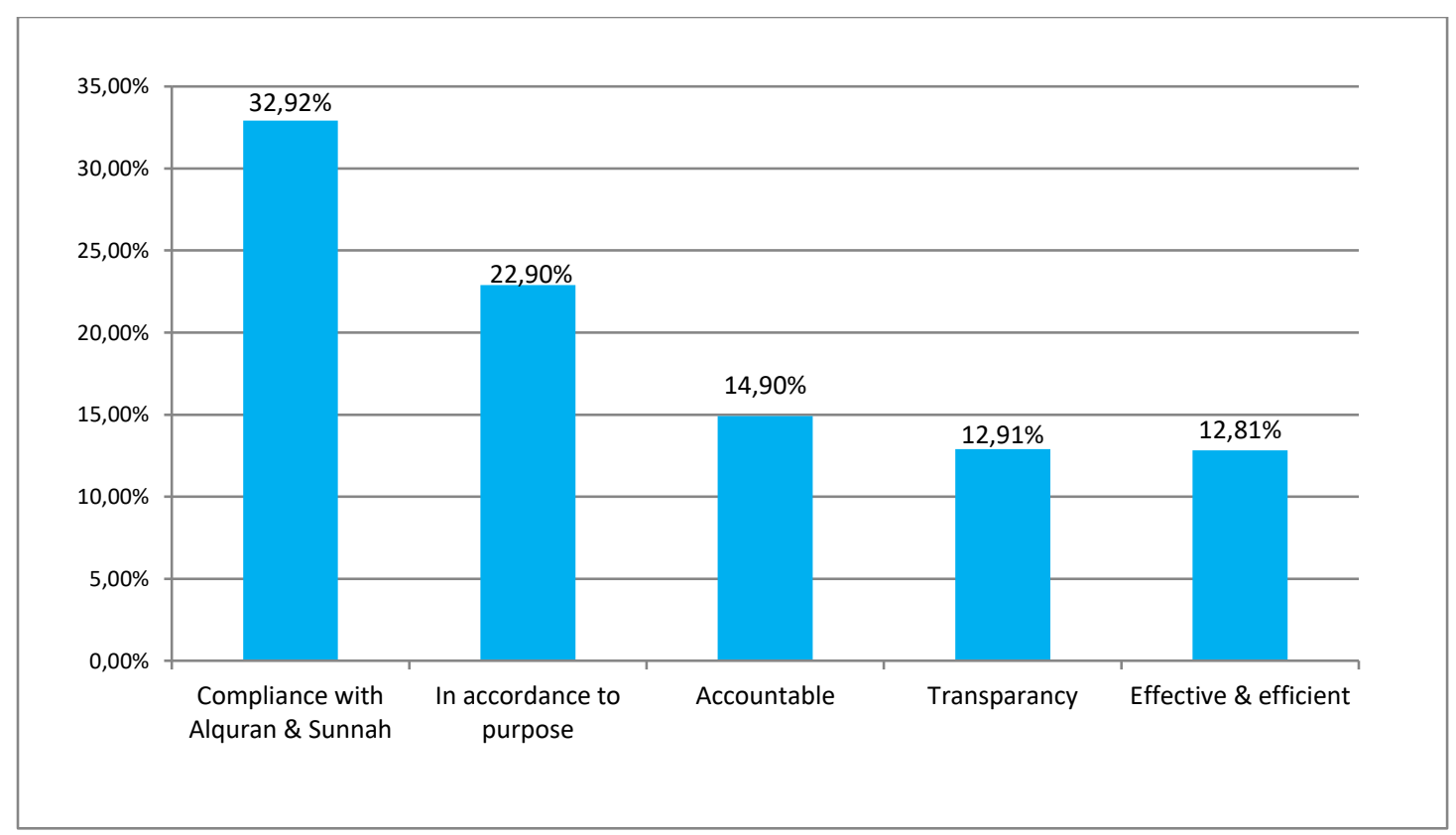

Figure 7. Policy Accountability Solution Criteria

Based on result of data process it is obtained that priority of the most priority process accountability in stipulating nazhir's accountability implementation in empowerment of productive waqf in Indonesia is in accordance with Al-Qur'an and sunnah under grade of $32.35 \%$, then followed by in accordance with public need of $18.83 \%$, transparent information of $17.29 \%$, integrated system of $13.80 \%$ and the last priority is transparent principle of $12.16 \%$. In calculation of local grade, it has confirmed that all pairwise comparisons have reached inconsistency level <10\%/0.01.

Result of agreement $(\mathrm{W})$ of all respondents is $40.98 \%$ means that interrespondent deal level upon priority level on criteria cluster of process accountability is adequately low. The low of inter-respondent deal level is in line with per-respondent synthesis result which shows that priority result has various answers. There are (4) elements become priority in this implementation of process accountability, as follows: 


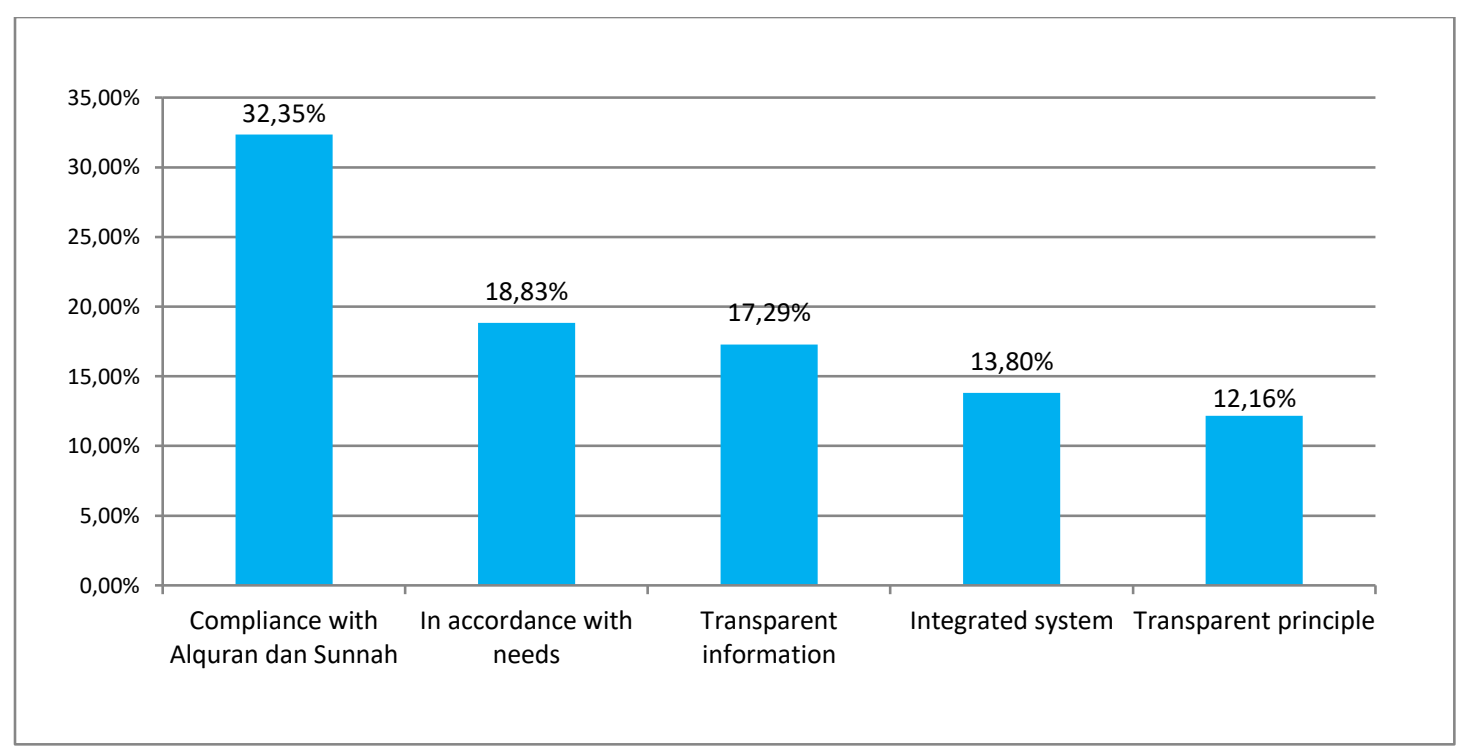

Figure 8. Elements in Implementation of Process Accountability

Based on result of data process it shows that the most priority strategy in stipulating nazhir's accountability strategy in empowerment of productive waqf in Indonesia is Indonesian Waqf Board's (BWI) strategy under grade of $34.07 \%$, then followed by Nazhir's strategy of $31.57 \%$, and the last priority is strategy of Ministry of Religion of $26.27 \%$. In calculation of local grade, it has confirmed that all pair-wise comparisons have reached inconsistency level $<10 \% / 0.01$. Result of agreement $(\mathrm{W})$ of all respondents is $51.49 \%$ means that inter-respondent deal level upon priority level on strategy cluster is adequately high. The high of inter-respondent deal level is in line with result of perrespondent synthesis which shows that priority result almost has sufficient various answers.

This research result shows that based on opinion of the experts, priority strategy for accountability implementation from the above three institutions shall be as follows: 


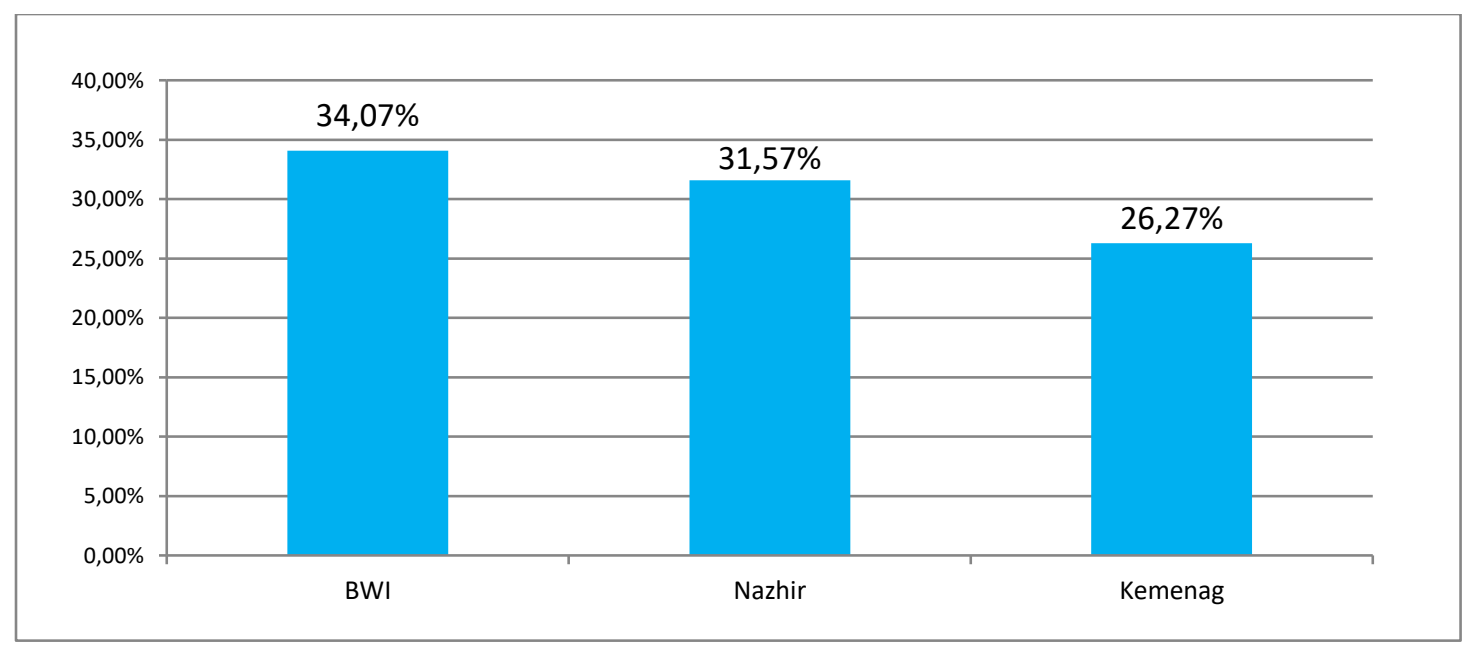

Figure 9. Institution's Strategy for Accountability Implementation

Based on joint opinion, the most priority BWI's strategy in stipulating nazhir's accountability strategy in empowerment of productive waqf in Indonesia is preparing guideline under grade of $23.74 \%$, then followed by need maping of $23.04 \%$, regulation socialization of $19.61 \%$, periodic training of $15.67 \%$ and the last priority is tight supervisory of $10.35 \%$. In calculation of local grade, it has confirmed that all pair-wise comparisons have reached inconsistency level $<10 \% / 0.01$. Result of agreement $(\mathrm{W})$ of all respondents is $35.55 \%$ means that inter-respondent deal level upon priority level on BWI's strategy cluster of process accountability is adequately low. Strategy formulation which may be implemented by BWI as follows:

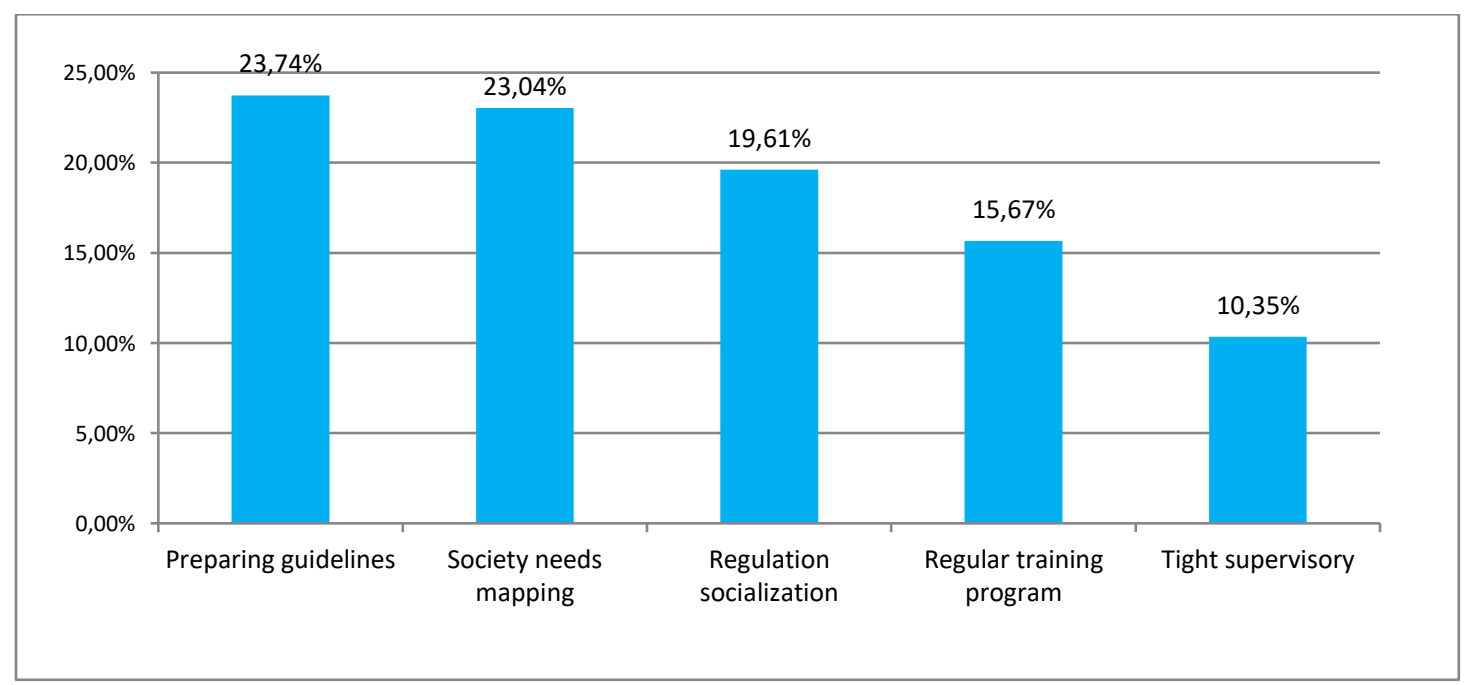

Figure 10. BWI's Strategy for Accountability Implementation 
The most priority nazhir's strategy in stipulating nazhir's accountability strategy in empowerment of productive waqf in Indonesia is strategy of interinstitution synergy under grade of $22.80 \%$, then followed by integrated system of $21.75 \%$, standardization of SOP $19.84 \%$, making periodic report of $15.96 \%$ and the last priority is comparative study of $10.74 \%$. In calculation of local grade, it has confirmed that all pair-wise comparisons have reached inconsistency level $<10 \% / 0.01$. Result of agreement $(\mathrm{W})$ of all respondents is $32.84 \%$ means that inter-respondent deal level upon priority level on BWI's strategy cluster of nazhirs's strategy is adequately low. The low of interrespondent deal level is in line with per-respondent synthesis result which shows that priority result has various answers. Strategies must be conducted by nazhir are:

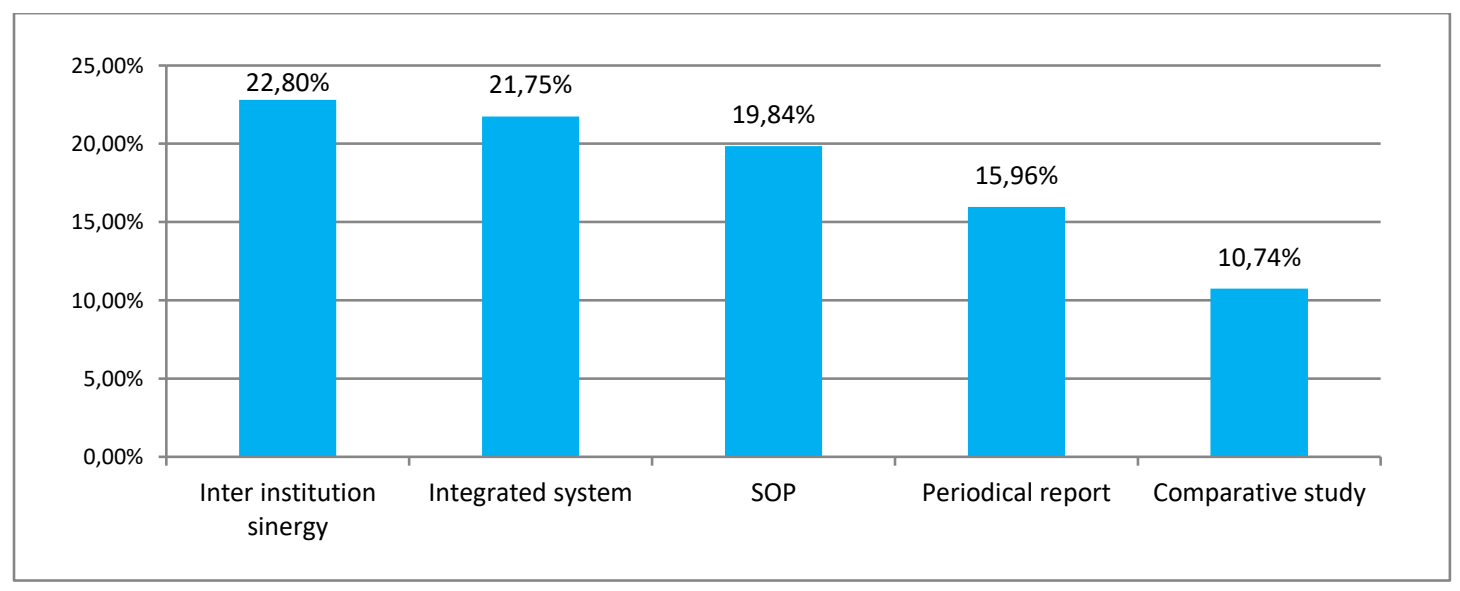

Figure 11. Nazhir's Strategy for Accountability Implementation

Based on joint opinion then, the main Kemenag's strategy in stipulating nazhir's accountability strategy in empowerment of productive waqf in Indonesia is strategy of waqf nazhir coaching under grade of $22.62 \%$, then followed by revision of Waqf Law of $20.45 \%$, duties and authorities division of $19.50 \%$, massive education of $16.91 \%$ and the last priority is consultant board of $8.84 \%$. In calculation of local grade, it has confirmed that all pair-wise comparisons have reached inconsistency level $<10 \% / 0.01$. Result of agreement (W) of all respondents is $37.78 \%$ means that inter-respondent deal level upon priority level on Kemenag's strategy cluster of nazhirs's strategy is adequately low. The low of inter-respondent deal level is in line with per-respondent 
synthesis result which shows that priority result has various answers. Five strategies must be conducted by Kemenag are:

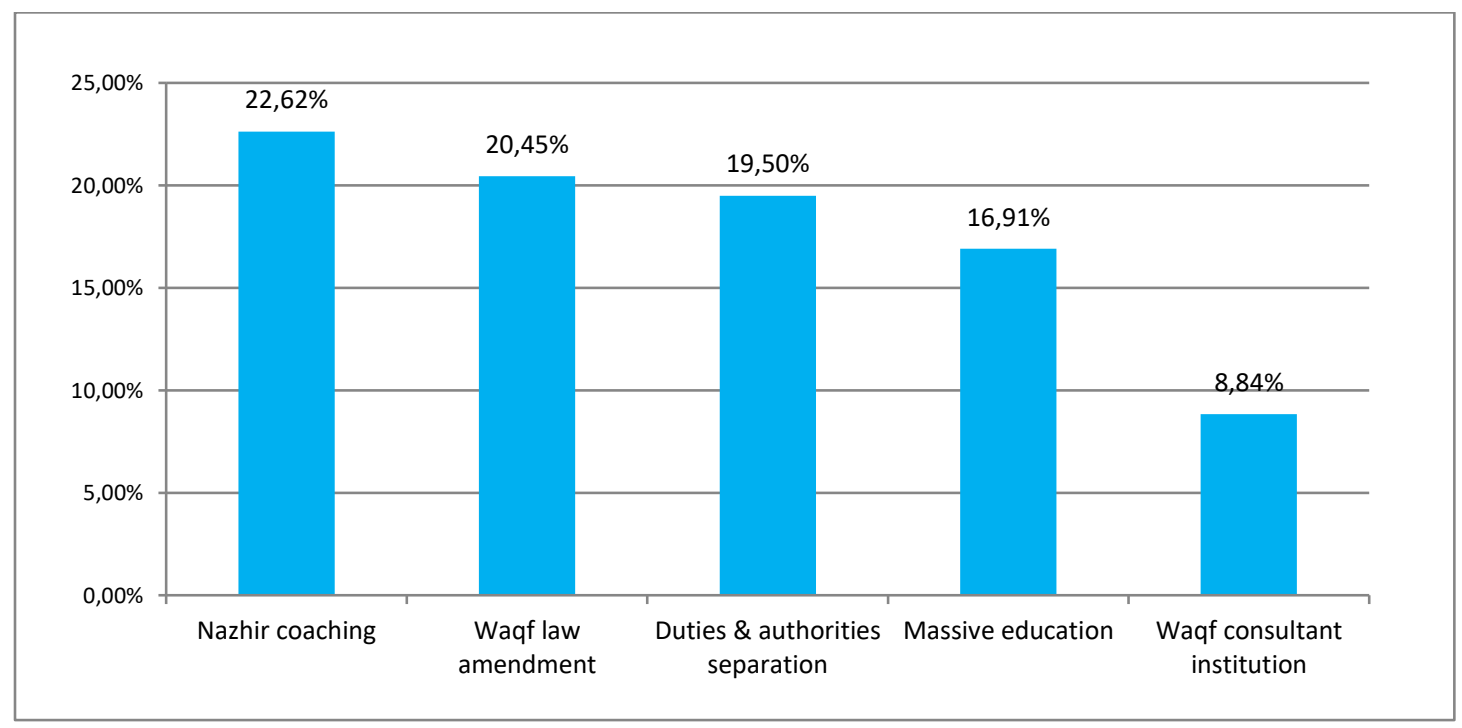

Figure 12. Ministry of Religion's Strategy for Accountability Implementation

The results of this study are in line with research conducted by Huda et al (2014) which stated that accountability is a solution for waqf management. It is also in line with the research conducted by Ihsan et al (2016). One of the results of his research stated that it is time for BWI to introduce and develop rules on how accountability should be applied

\section{Conclusion}

Based on conducted research, at the end of this research it may be taken a conclusion that accountability implementation on waqf institution (nazhir) in Indonesia is very poor and much low from the expectation. Most available nazhirs have not implemented accountability due to some faced constraint factors include: the lack of nazhir and public comprehension regarding on waqf, non-professional nazhir, management system which remains simple (traditional), less budget, as well as regulator institutions (Kemenag and BWI) which have not been maximal in preparing productive waqf nazhir. Solution practicable may be shown on the previous discussion, while priority strategies which required to be executed are strategy of BWI, Nazhir and Kemenag. 
Productive Waqf must have human resources with high professionalism so that can make innovations in the development of the waqf assets under its management. Nazhir is expected to arrange an inter-integration system. Nazhir must synergize with other institutions to develop productive waqf management so that the results will be maximized for the welfare of the people. BWI and the Ministry of Religion must upgrade their role to be able help nazhir manage waqf productively and efficiently both through regulation and through real development programs.

\section{References}

Ascarya, Rahmawati, and Hosen. (2016). Merancang Model-model Wakaf Produktif. Departemen Ekonomi dan Keuangan Syariah Bank Indonesia.

Asytuti, R. (2012). Optimalisasi Wakaf Produktif. Jurnal Studi Ekonomi AtTaradhi, Vol. 3(1): 45-54.

Budiman, A. A. (2011). Akuntabilitas Pengelola Lembaga Wakaf. Jurnal Walisongo,Vol. 19(1): 75-102.

Darwanto. (2012). Wakaf Sebagai Alternatif Pendanaan Penguatan Ekonomi Masyarakat Indonesia. Jurnal Ilmu Manajemen dan Akuntansi Terapan,Vol. 3(1).

Huda, N. et al. (2014). Akuntabilitas Sebagai Sebuah Solusi Pengelolaan Wakaf. Jurnal Akuntansi Multiparadigma, Vol. 5: 485-497.

Ihsan, H. Hameed, S. and Ibrahim, M. (2011). WAQF Accounting and Management in Indonesian WAQF Institutions, The Cases of Two WAQF Foundations. Humanomics, Vol. 27(4): 252-289.

Ihsan, H. and Septriani, Y. (2016). Akuntabilitas pada Institusi Wakaf; Studi Kasus pada Wakaf Daarut Tauhid. National Conference of Applied Engineering, Business and Information Technology, Politeknik Negeri Padang, 177-187, 2016.

Lita, H. N. (2015). Implementation of Corporate Social Responsibility (CSR) Through Waqf Related to Law Number 41 Year 2004 on Waqf. Tazkia Islamic Finance and Business Review, Vol. 9(1).

Masruki, Shafii. (2013). The Development of Waqf Accountingin Enchanging Accuntability. Midle East Journal of Scientific Research, Vol. 13: 01-06. ISSN1990-9233

Osman, A. Z. (2010). Accountability of Waqf Management: Insight From Praxis of Nongovernmental Organisation (NGO). Seventh International Conference-The Tawhidi Epistemology: Zakat and Waqf Economy, Bangi, 153$175,2010$. 
Ridwan, M. (2012). Nazhir Profesional Kunci Kesuksesan Wakaf Produktif.Jurnal Muqtasid, Vol. 3(1).

Siraj, S. A. Ismail, Y. (2015). Strategic Planning and Accountability of Waqf Management in Malaysia. $4^{\text {th }}$ International Conference on Inclusive Islamic Financial Sector Development, 2015.

Siswantoro, D. (2017). Islamic Accountability Index of Cash Waqf Institutionin Indonesia. Competition and Cooperation in Economics and Business, 47-53, 2017. ISBN978-1-138-62666-9. 